\title{
Polymyalgia rheumatica in a married couple
}

This article was published in the following Dove Press journal:

International Journal of General Medicine

2I August 2012

Number of times this article has been viewed

\section{Christoph Alexander Rüst ${ }^{1}$ \\ Beat Knechtle ${ }^{1,2}$ \\ Thomas Rosemann' \\ Felix Wermelinger ${ }^{3}$}

'Institute of General Practice and Health Services Research, University of Zurich, Zurich, Switzerland;

${ }^{2}$ St Gallen Health Center,

St Gallen, Switzerland; ${ }^{3}$ Department of Rheumatology, University Hospital, University of Bern, Switzerland
Correspondence: Beat Knechtle Facharzt FMH für Allgemeinmedizin, Gesundheitszentrum St Gallen, Vadianstrasse 26, 900I St Gallen, Switzerland

Tel +4I 7| 2268282

Fax +4| 7| 2268272

Email beat.knechtle@hispeed.ch
Abstract: The case of a married couple developing polymyalgia rheumatica (PMR) consecutively is presented. The 55-year-old wife complained in June 2010 about pain in her neck. Case history, physical examination, and erythrocyte sedimentation rate (ESR) of $80 \mathrm{~mm} /$ hour led to the diagnosis of PMR. In May 2011, her 66-year old husband complained about pain in his neck, shoulders, buttocks, and thighs. Considering anamnesis, physical examination, and ESR of $56 \mathrm{~mm} /$ hour, the diagnosis of PMR was made. Both wife and husband responded to steroid treatment. When the steroid dose was gradually reduced, both patients relapsed. In order to lower the cumulative dose of glucocorticoid therapy, $10 \mathrm{mg}$ methotrexate per week was added. In the literature, six cases of polymyalgia rheumatica in married couples have been described to date. In four cases, polymyalgia rheumatica occurred first in the wife. The interval of the diagnosis between the spouses ranged from 0 to 89 months. Although in most of the previous case reports a genetic disposition and an infectious agent have been discussed, this hypothesis must be questioned.

Keywords: husband, wife, erythrocyte sedimentation rate, C-reactive protein, polymyalgia rheumatica

\section{Introduction}

Polymyalgia rheumatica (PMR) is a relatively frequent disease with a prevalence between 13/100,000 and 133/100,000, with a predominance of people aged $>70$ years. ${ }^{1,2}$ It has been proposed that environmental factors and infectious agents are plausible in the etiology and pathogenesis of PMR. ${ }^{3}$ In this context, six case reports have been published to date in which PMR has been diagnosed in married couples. ${ }^{4-9}$ Also, there have been some reports describing several cases of PMR within family members such as siblings. ${ }^{9-15}$ Based upon these reports, it has been discussed that a genetic predisposition might exist ${ }^{9,10,12-16}$ and an infective agent might be implicated in the pathogenesis of this disease. ${ }^{9,10,12-15}$ We present a further case report of PMR in a married couple.

\section{Case presentation Wife}

The 55-year-old wife, working as housewife and accordion teacher, complained in June 2010 about pain in her neck. She recognized it when she had problems rotating her head while driving her car. In the following months, the pain extended to the shoulders and the arms. The physical examination of the $156 \mathrm{~cm}, 68 \mathrm{~kg}$ woman showed a limited mobility 
of the upper limbs, with no limitation of the flexibility of the hip and lower limbs. Magnetic resonance tomography showed a disk prolapse at C3/C4. In October 2010, laboratory parameters were determined, and erythrocyte sedimentation rate (ESR) was at $80 \mathrm{~mm} / \mathrm{h}$. Rheumatoid factor (RF) and anticitrullinated protein antibody (ACPA) were negative. In her family history, her father had died at the age of 79 years after three apoplectic strokes while her mother was still alive at the age of 92 years. She had two brothers and two sisters; the younger sister had breast cancer. A rheumatologist was consulted, and a diagnosis of PMR was established. Figure 1 shows the course of ESR and C-reactive protein (CRP). Upon diagnosis, therapy with $40 \mathrm{mg}$ of prednisone was started, with reduction by $10 \mathrm{mg}$ every month down to $10 \mathrm{mg}$ prednisone. Unfortunately, she suffered from side effects of prednisone, such as an increase in body mass. In order to lower the cumulative dose of glucocorticoid therapy, $10 \mathrm{mg}$ methotrexate per week was added. ${ }^{17}$ Between January 2011 and April 2012, she received $10 \mathrm{mg}$ prednisone daily and $10 \mathrm{mg}$ methotrexate weekly.

Figure 1 Time course of erythrocyte sedimentation rate (ESR) and C-reactive protein (CRP) for wife (panel A) and husband (panel B).

\section{Husband}

In May 2011, the 66-year-old husband also complained about pain in his neck, shoulders, buttocks, and thighs. In addition, he lost $7 \mathrm{~kg}$ of body weight within a period of 6 months. An extensive examination with abdomen sonography, chest radiography, and laboratory analyses was performed in order to exclude cancer. His ESR was $56 \mathrm{~mm} /$ hour, and a rheumatologist (different from the one the wife visited) was consulted. Physical examination revealed an unlimited but painful mobility of the upper limbs. He suffered from pain on palpation on both shoulders, both upper arms, and both thighs. RF and ACPA were negative. Data for his family history were lacking since he grew up in a children's home and was placed with foster parents later. He had four siblings with no rheumatic diseases. Prior to his retirement at the age of 60 years, he had worked as a police officer and postal van driver. Eleven months after the first symptoms of his wife, he also received a diagnosis of PMR. Figure 1 shows the course of ESR and CRP. The husband was afraid to take prednisone due to the side effects of prednisone his wife had experienced. Since his wife could lower prednisone intake due to the simultaneous intake of methotrexate, he finally agreed also to start with prednisone, and ESR started to drop. Upon diagnosis, he received $10 \mathrm{mg}$ prednisone daily and $10 \mathrm{mg}$ methotrexate weekly.

Following the 2012 provisional classification criteria for polymyalgia rheumatica, with a scoring algorithm taking into account morning stiffness $>45$ minutes ( 2 points), hip pain/ limited range of motion (1 point), absence of RF and/or ACPA (2 points), and absence of peripheral joint pain (1 point), the wife got 4 points and the husband 5 points. ${ }^{18}$ According to these provisional classification criteria, patients $\geq 50$ years old presenting with bilateral shoulder pain that is unexplained by an alternative pathology can be classified as having PMR in the presence of morning stiffness $>45$ minutes, elevated CRP, and/or ESR, and new hip pain. ${ }^{18}$

\section{Discussion}

PMR is clinically characterized by severe bilateral muscle pain and aching involving the neck, shoulders, and pelvic girdles associated with morning stiffness. ${ }^{19}$ ESR is generally markedly elevated, and both clinical symptoms and elevated
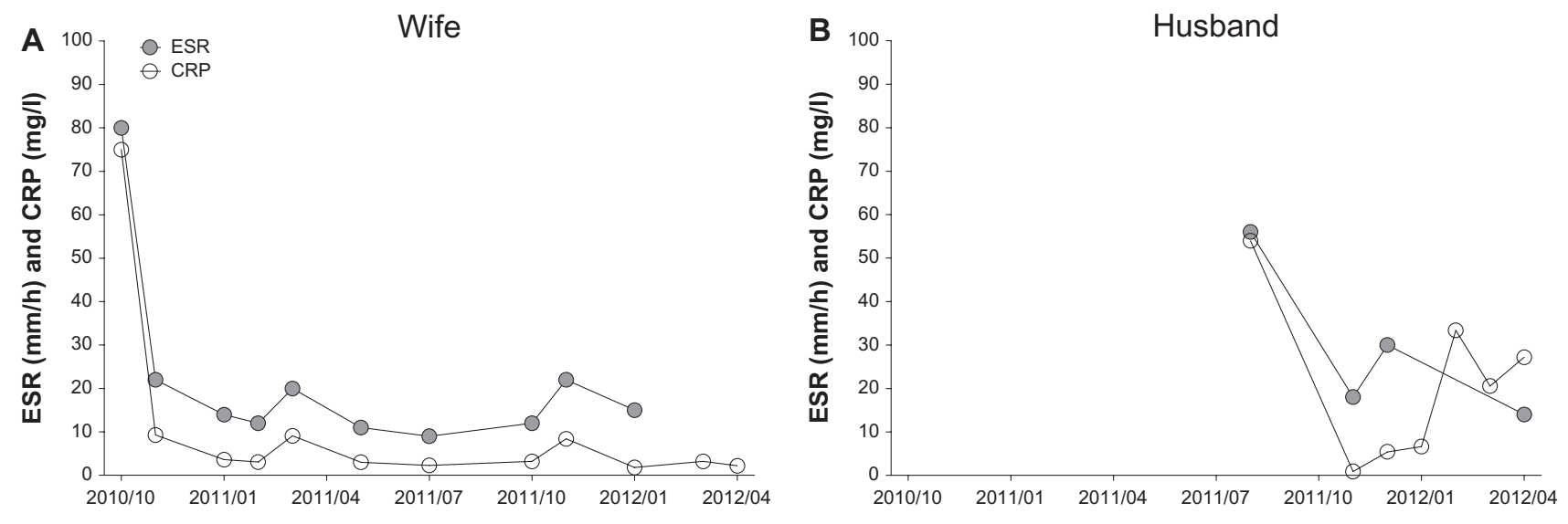

Figure I Time course of erythrocyte sedimentation rate (ESR) and C-reactive protein (CRP) for wife (panel A) and husband (panel B). 
ESR decline after treatment with high-dose prednisone. ${ }^{20}$ As the syndrome is defined by nonspecific elements and a classification overlap with giant-cell arteritis (GCA), the multiple classification criteria mention that other diseases have to be excluded. There is indeed a wide range of diagnostic procedures looking especially for large-vessel vasculitis, calcium pyrophosphate deposition disease (CPPD), and late-onset rheumatoid arthritis (LORA), and a pragmatic approach by the general practitioner.

In this couple, PMR occurred first in the wife, then in the husband. Regarding the six reported cases in the literature, an interesting finding was that PMR occurred in four of six cases first in the wife (Table 1), as was the case in the present couple. Generally, a ratio of 3:1 of women to men is reported for PMR. ${ }^{1}$ In contrast to the existing case reports (Table 1) with PMR in married couples, the present couple was younger but still aged over 50 years, where PMR is frequent. ${ }^{1}$ In our two patients treated pragmatically with prednisone, neither GCA, CPPD, nor LORA have been definitely excluded. One may weigh the differential diagnosis by the initial dose of prednisone to suppress the symptoms with lower doses in case of CPPD-disease or "pure PMR" without GCA. In addition, there may be relapses of the symptoms during the tapering of glucocorticoids in cases of GCA, even without cranial symptoms, as the incidence of occult giant-cell arteritis is clinically underestimated.

Our couple originated from northern Europe. The reported cases of PMR in married couples occurred in Denmark, ${ }^{8}$ Sweden, ${ }^{8}$ Norway, ${ }^{9}$ Scotland, ${ }^{15}$ Israel, ${ }^{9}$ and the USA. ${ }^{6,12}$ It has been reported that the prevalence of PMR is higher in individuals of Scandinavian background. ${ }^{1}$ In Southern Europe, the annual incidence of PMR was considerably lower. ${ }^{1}$

Case reports on PMR were published between 1974 and 1992. ${ }^{4-9}$ During the last 20 years, no case of PMR in a married couple occurred, or it was not published. Although in most of these cases, a genetic disposition ${ }^{5,8,9}$ and an infectious agent ${ }^{6,7,9}$ have been discussed, it is difficult to build up this hypothesis on a few case reports. Moss and Soukop concluded that "a powerful argument against an infective etiology remains the long time interval which

Table I Case reports with polymyalgia rheumatica in married couples in the literature

\begin{tabular}{|c|c|c|c|c|c|c|}
\hline \multicolumn{2}{|l|}{ Husband } & \multicolumn{2}{|l|}{ Wife } & \multirow{2}{*}{$\begin{array}{l}\text { Interval between } \\
\text { appearance } \\
\text { (months) }\end{array}$} & \multirow[t]{2}{*}{ Details } & \multirow[t]{2}{*}{ Reference } \\
\hline $\begin{array}{l}\text { Age at } \\
\text { diagnosis } \\
\text { (years) }\end{array}$ & $\begin{array}{l}\text { ESR at } \\
\text { diagnosis } \\
(\mathrm{mm})\end{array}$ & $\begin{array}{l}\text { Age at } \\
\text { diagnosis } \\
\text { (years) }\end{array}$ & $\begin{array}{l}\text { ESR at } \\
\text { diagnosis } \\
(\mathrm{mm})\end{array}$ & & & \\
\hline 78 & 95 & $76^{\#}$ & 98 & 8 & $\begin{array}{l}\text { In the wife, treatment with } 10 \text { mg prednisone } \\
\text { was started and all symptoms disappeared } \\
\text { after } 48 \text { hours. In the husband, treatment } \\
\text { with } 60 \mathrm{mg} \text { prednisone was ineffective, } \\
\text { but after } 100 \mathrm{mg} \text { prednisone, a marked } \\
\text { improvement was noted after } 48 \text { hours. }\end{array}$ & 7 \\
\hline $7 I^{\#}$ & 49 & 69 & 58 & 0 & $\begin{array}{l}\text { The wife presented the day after her spouse } \\
\text { with clinical symptoms. Both patients were } \\
\text { treated with prednisone and symptoms } \\
\text { regressed. }\end{array}$ & 6 \\
\hline 76 & 72 & $78^{\#}$ & 64 & 1 & $\begin{array}{l}\text { Husband and wife began suffering from } \\
\text { the disease within the same month and an } \\
\text { infectious etiology seemed plausible. } \\
\text { Both were HLA-B8-positive. }\end{array}$ & 10 \\
\hline 69 & 78 & $69^{\#}$ & 57 & 24 & $\begin{array}{l}\text { In both patients, low-dose prednisone } \\
\text { therapy continued. }\end{array}$ & 9 \\
\hline 78 & 119 & $74^{\#}$ & 92 & 83 & $\begin{array}{l}\text { The husband's PMR symptoms started } \\
4 \text { years after his wife's death. }\end{array}$ & 8 \\
\hline $68^{\#}$ & 60 & 70 & 133 & 89 & $\begin{array}{l}\text { Five family members with PMR or an illness } \\
\text { compatible with PMR were reported. } \\
\text { The husband developed the disease } \\
6-7 \text { years earlier than the siblings, highly } \\
\text { suggestive that the disease was caused by } \\
\text { an infectious agent and genetic disposition } \\
\text { is essential for the development of PMR. }\end{array}$ & II \\
\hline
\end{tabular}

Note: "First diagnosis.

Abbreviations: ESR, erythrocyte sedimentation rate; PMR, polymyalgia rheumatica; HLA, human leukocyte antigen. 
may separate the onset of symptoms in family members or conjugal pairs." ${ }^{15}$ In the present couple, we have no data from the family history of the husband since he grew up in a children's home and was placed with foster parents later. A genetic relation between husband and wife is unlikely, but therefore cannot be definitely excluded. However, PMR in a married couple argues against genetic background, and this observation proposes an environmental trigger to the disease.

Treatment with $10-20 \mathrm{mg}$ of prednisone daily is suggested for PMR. ${ }^{21}$ There are no recommendations in guidelines regarding the exact dose or duration of administration; the drugs and the rate of reduction of prednisone should be adjusted depending on the individual's response and with consideration of the multiple risks of high-dose and long-term glucocorticoids. ${ }^{21}$ A prolonged course of treatment is necessary, and corticosteroids are gradually tapered, guided by regular clinical evaluation and ESR (and/or CRP) measurement. Methotrexate is the beststudied corticosteroid-sparing agent, and may be useful for patients with frequent disease relapses and/or corticosteroidrelated toxicity. ${ }^{22}$ However, superiority of a combination therapy in reducing the incidence of glucocorticoid-related complications has not been shown yet. ${ }^{23}$

\section{Disclosure}

The authors have no conflict of interest in this work.

\section{References}

1. Gonzalez-Gay MA, Vazquez-Rodriguez TR, Lopez-Diaz MJ, et al. Epidemiology of giant cell arteritis and polymyalgia rheumatica. Arthritis Rheum. 2009;61:1454-1461.

2. Huston KA, Hunder GG, Lie JT, Kennedy RH, Elveback LR. Temporal arteritis: a 25-year epidemiologic, clinical, and pathologic study. Ann Intern Med. 1978;88:162-167.

3. Gonzalez-Gay MA, Garcia-Porrua C. Epidemiology of the vasculitides. Rheum Dis Clin North Am. 2001;27:729-749.

4. Faerk KK. Simultaneous occurrence of polymyalgia rheumatica in a married couple. J Intern Med. 1992;231:621-622.

5. Garfinkel D, Bograd H, Salamon F, et al. Polymyalgia rheumatica and temporal arteritis in a married couple. Am J Med Sci. 1984;287: 48-49.
6. Hickstein DD, Gravelyn TR, Wharton M. Giant cell arteritis and polymyalgia rheumatica in a conjugal pair. Arthritis Rheum. 1981;24: 1448-1450.

7. Kyle MV, Hazleman BL, King RH. Polymyalgia rheumatica/giant cell arteritis in husband and wife. Clin Rheumatol. 1984;3:395-396.

8. Nielsen JL. Polymyalgia rheumatica in a husband and wife. Scand $J$ Rheumatol. 1980;9:177-178.

9. Kvernebo K, Brath HK. Polymyalgia arteritica. A report on five cases within a family. Scand J Rheumatol. 1980;9:187-189.

10. Bartolome MJ, Martínez-Taboda VM, Lopez-Hoyos M, Blanco R, Rodriguez-Valverde V. Familial aggregation of polymyalgia rheumatica and giant cell arteritis: genetic and T cell repertoire analysis. Clin Exp Rheumatol. 2001;19:259-264.

11. Granato JE, Abben RP, May WS. Familial association of giant cell arteritis. A case report and brief review. Arch Intern Med. 1981;141: 115-117.

12. Liang GC, Simkin PA, Hunder GG, Wilske KR, Healey LA. Familial aggregation of polymyalgia rheumatica and giant cell arteritis. Arthritis Rheum. 1974;17:19-24.

13. Liozon E, Ouattara B, Rhaiem K, et al. Familial aggregation in giant cell arteritis and polymyalgia rheumatica: a comprehensive literature review including 4 new families. Clin Exp Rheumatol. 2009;27:S89-S94.

14. Mathewson JA, Hunder GG. Giant cell arteritis in two brothers. J Rheumatol. 1986;13:190-192.

15. Moss RR, Soukop M. Polymyalgia rheumatica in a sibling pair. Two case reports and a brief review of the literature. Scott Med J. 1988;33: 342-343.

16. Fietta P, Manganelli P, Zanetti A, Neri TM. Familial giant cell arteritis and polymyalgia rheumatica: aggregation in 2 families. $J$ Rheumatol. 2002;29:1551-1555.

17. Spies CM, Burmester GR, Buttgereit F. Methotrexate treatment in large vessel vasculitis and polymyalgia rheumatica. Clin Exp Rheumatol. 2010;28:S172-S177.

18. Dasgupta B, Cimmino MA, Maradit-Kremers H, et al. 2012 provisional classification criteria for polymyalgia rheumatica: a European League Against Rheumatism/American College of Rheumatology collaborative initiative. Ann Rheum Dis. 2012;71:484-492.

19. Salvarani C, Cantini F, Boiardi L, Hunder GG. Polymyalgia rheumatica and giant-cell arteritis [review]. N Engl J Med. 2002;347:261-271.

20. Caporali R, Cimmino MA, Montecucco C, Cutolo M. Glucocorticoid treatment of polymyalgia rheumatica. Clin Exp Rheumatol. 2011;29: S143-S147.

21. Charlton R. Optimal management of giant cell arteritis and polymyalgia rheumatica. Ther Clin Risk Manag. 2012;8:173-179.

22. Schmidt J, Warrington KJ. Polymyalgia rheumatica and giant cell arteritis in older patients: diagnosis and pharmacological management. Drugs Aging. 2011;28:651-666.

23. Spies CM, Burmester GR, Buttgereit F. Methotrexate treatment in large vessel vasculitis and polymyalgia rheumatica. Clin Exp Rheumatol. 2010;28:S172-S177.
International Journal of General Medicine

\section{Publish your work in this journal}

The International Journal of General Medicine is an international, peer-reviewed open-access journal that focuses on general and internal medicine, pathogenesis, epidemiology, diagnosis, monitoring and treatment protocols. The journal is characterized by the rapid reporting of reviews, original research and clinical studies across all disease areas.

\section{Dovepress}

A key focus is the elucidation of disease processes and management protocols resulting in improved outcomes for the patient.The manuscript management system is completely online and includes a very quick and fair peer-review system. Visit http://www.dovepress.com/ testimonials.php to read real quotes from published authors. 